\title{
Emulsion Formulations of Indomethacine and Xylometazoline Hydrochloride for Intranasal Delivery
}

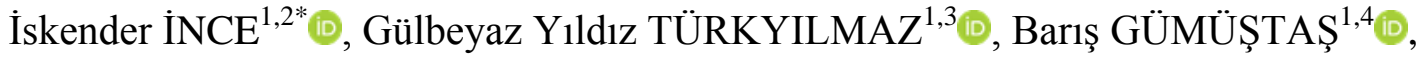 Cemal CINGI ${ }^{5}$ iD, Yeşim KARASULU ${ }^{3}$}

${ }^{1}$ Ege University, Center for Drug R\&D and Pharmacokinetic Applications (ARGEFAR), Izmir, Turkey
${ }^{2}$ Ege University, Institute of Nuclear Sciences, Department of Nuclear Application, Izmir, Turkey
${ }^{3}$ Ege University, Faculty of Pharmacy, Department of Pharmaceutical Technology, Izmir, Turkey
${ }^{4}$ Ege University, Faculty of Science, Department of Chemistry, Izmir, Turkey
${ }^{5}$ Osmangazi University, Department of Otorhinolaryngology-Head and Neck Surgery, Eskişehir, Turkey

Geliş / Received: 07/12/2020, Kabul / Accepted: 21/12/2020

\begin{abstract}
Nasal administration has many advantages over parenteral and oral administration. Some drugs are ineffective when administered orally due to absorption and first pass metabolism. Therefore, if the aqueous solubility problem can be overcome, the intranasal route will be an alternative method for administration. In this study, emulsion formulation was proposed as a new approach in order to increase the duration of the indomethacinxylometazoline hydrochloride combination in the nose. The $\mathrm{pH}$ value of $\mathrm{F} 1$ and F2 emulsions were determined 9.4 and as 5.6 respectively. The particle size of F1 and F2 formulations were found to be $136.8 \pm 24$ $\mathrm{nm}$ and $269.5 \pm 66 \mathrm{~nm}$ respectively.
\end{abstract}

Formulation of o/w emulsion IND and XYL may be considered as an alternative to iv and po administration. This administration of drugs may be delivery to achieve rapid onset of its pharmacological effect.

Keywords: Emulsion, Indomethacine, xylometazoline hydrochloride, intranasal delivery

$\ddot{O} \mathbf{z}$

Nazal yolla ilaç uygulamanın, parenteral ve oral uygulamaya nazaran birçok avantajı vardır. Bazı ilaçlar emilim ve ilk geçiş metabolizması nedeniyle ağızdan uygulandığında etkisizdir. Bu nedenle, sulu çözünürlük probleminin üstesinden gelinebilirse, burun içi yol uygulama için alternatif bir yöntem olacaktır. Bu çalışmada, indometazin-ksilometazolin hidroklorür kombinasyonunun burunda kalma süresinin uzatmak amacıyla emülsiyon formülasyonu yeni bir yaklaşım olarak önerilmiştir. F1 ve F2 emülsiyonlarının pH değeri sırasıyla 9,4 ve 5,6 olarak belirlenmiştir. F1 ve F2 formülasyonlarının partikül boyutunun sırasıyla $136.8 \pm 24$ nm ve $269.5 \pm 66 \mathrm{~nm}$ olduğu bulunmuştur.

İndometazin-ksilometazolin içeren y/s emülsiyon formülasyonu, iv ve po uygulamasına bir alternatif olarak düşünülebilir. Bu ilaç uygulaması, farmakolojik etkisinin hızlı başlangıcını sağlamak için verilebilir.

Anahtar Kelimeler: Emülsiyon, indometazin, ksilometazolin hidroklorür, intranazal uygulama 


\section{Introduction}

Emulsion refers to a mixture that includes two or more liquid phases. Emulsions can be categorized as water-in-oil emulsions (with water droplets as a dispersed phase in the flow of oil as the continuous phase), oil-inwater emulsions (with oil droplets in the flow of water), and more complex configurations of emulsions such as water-in-oil-in-water emulsions.

Nasal route; systemically effective drugs have also been the route of administration with advantages such as easily accessible, large surface area, thin membrane feature and excess vascularity, and elimination of hepatic first passage.

The nasal cavity is mainly used for treatment of local diseases of the upper respiratory tract such as nasal congestion, nasal infections and nasal allergic diseases e.g. allergic rhinitis. Hydrophobic drugs with low molecular weight applied nasally are used for the treatment of nasal mucosa and sinus. (Matsuyama et al. (2006), Mitra et al. (2000), Shekade et al. (2020))

Indomethacin (IND), a lipophilic model drug in this study, is an anti-inflammatory and analgesic antipyretic drug used in experiments. It produces erosions and ulcers in the gastrointestinal tract. An alternative route of administration for IND would allow blood drug concentrations to be maintained in the therapeutic range while avoiding gastric irritation. Huang et al. (1995) showed that IND solutions could easily pass through the nasal mucosa in rats and enter the systemic circulation. In this study, nasal absorption was close to that obtained after per oral (po) dosing (Karasulu et al (2008)). Xylometazoline $\mathrm{HCl}$ (XYL) is applied topically to relieve nasal congestion associated with acute or chronic rhinitis, common cold, sinusitis, hay fever or other allergies. It causes vasoconstriction in the nasal submucosa, which is manifested as a collapse of the venous sinusoids. Xylometazoline $\mathrm{HCl}$ action is characterized by a fast onset with an effect obtained after 5-10 minutes and lasting for 6-8 hours. The efficacy of xylometazoline $\mathrm{HCl}$ as a topical nasal decongestant is well proven. (Graf et al. (2018))

It is usual for surgery to result in inflammation, causing postoperative pain and edema. Possible pain and inflammation are also common problems, especially after rhinoplasty, and the active ingredient of indomethacin, which is a non-steroidal antiinflammatory group, has been included in the formulation as both analgesic and antiinflammatory. Edema is the most uncomfortable situation in patients who have undergone nasal surgery, especially in the postoperative period, and xylometazoline was added as a decongestant to prevent edema.

The aim of this study is the preparation and quality control studies of an emulsion formulation containing indomethacinxylometazoline that can be applied intranasally.

\section{Material and Methods}

\section{Materials}

IND and XYL $\mathrm{HCl}$ were kindly supplied by Deva Pharmaceutical Fac. (Istanbul, Turkey) and Berko Pharmaceutical Fac. (Istanbul, Turkey) respectively. The emulsifying agents; polyoxyethylene 20 sorbitan monooleate (Tween 80) and sorbitan monooleate (Span 80) were purchased from E. Merck. Co (Schuchardt, Germany). Ethyl alcohol was used as a cosurfactant and purchased from E. Merck. Co (Schuchardt, Germany). Methanol and acetonitrile were obtained from Carlo Erba. Sodium acetate 
and acetic acid were purchased from Merck. Water was purified by a Milli-Q Water Purification System (Direct-Q 8 UV). The black seed oil as an oily phase was purchased from Zade Vital Pharmaceuticals (Konya, Turkey). All chemicals were used as analytical grade.

\section{Preparation and charcterization of intranasal emulsions}

Two diffent type of oil-in-water (F1-O/W and $\mathrm{F} 2-\mathrm{O} / \mathrm{W}$ ) emulsions of black seed oil were prepared using different ratio emulsifying agents (Table 1).

Ethyl alcohol was added as cosurfactant. Isotonic phosphate buffer and sodium carbonate solution were used as the aqueous phase of emulsions. IND and XYL were incorporated into the oil phases and water phase of emulsions respectively and they were stirred with magnetic stirrer at 1000 rpm for $5 \mathrm{~min}$. All emulsions were stable and neutral $\mathrm{pH}$ during the time course of the experiments.

Table 1. The composition (\%), particle size distribution, viscosity and final drug loading of water in two different oil emulsion $(\mathrm{O} / \mathrm{W})$. Each value represents the mean $\pm \mathrm{SD}(\mathrm{n}=3)$

\begin{tabular}{llc}
\hline & F1 & F2 \\
\hline Black seed oil & 21.4 & 22 \\
Tween 80 & 20.6 & 22.5 \\
Span 80 & 3.6 & 2.5 \\
Ethyl Alcohol & 8.5 & 8.5 \\
Isotonic Phosphate & - & 42.5 \\
Buffer & & \\
Sodium carbonate & 40 & - \\
solution (2.5\%) & & \\
Distilled water & 14 & - \\
IND & 0.3 & 0.15 \\
XYL & 0.1 & 0.1 \\
\hline
\end{tabular}

For the characterization studies, the droplet size distribution and average droplet size of emulsions were measured using Zetasizer 3000 HSA (Malvern, UK). The viscosity of emulsions were measured on a Brookfield viscometer, model DV-II+PRO spindle ULA, I equipment with Rheocalc V1.1 software,
Brookfield Engineering Laboratories Inc. (Massachusetts, USA).

\section{Preparation of nasal indomethacin solution}

For permeation studies, IND and XYL were solved with isotonic phosphate buffer: ethanol (3:2) and isotonic phosphate buffer respectively (IND-Sol and XYL-Sol). All solutions was freshly prepared daily.

\section{Drug content studies \\ Preparation of stock solutions}

Stock solutions of indomethazin and xylometazoline were prepared by dissolving $10 \mathrm{mg}$ of each compound in $10 \mathrm{~mL}$ methanol. These solutions were stored at $4{ }^{\circ} \mathrm{C}$ and were stable for at least three weeks. Working standard solutions were prepared by diluting the stock solution $(5.0,10.0,20.0,50.0$ and $100.0 \mu \mathrm{g} / \mathrm{mL}$ for xylometazoline, 1.0, 5.0, $10.0, \quad 25.0$ and $50.0 \mu \mathrm{g} / \mathrm{mL}$ for indomethazin).

\section{Equipment and Chromatographic Conditions}

Shimadzu HPLC system has been employed to apply the method. System consists of a degasser unit (DGU-20A SR), a quaternary pump (LC-20AT), an auto injector (SIL20AC HT), column oven (CTO-10AS VP) and communications bus module (CBM20A). The system was equipped with a PDA detector (SPD-M20A).

The chromatographic separation was performed on a ACE 5 C18 column $(250 \mathrm{x}$ $4.6 \mathrm{~mm}, 5 \mu \mathrm{m})$. The mobile phase consisted of $10 \mathrm{mM}$ sodium acetate buffer $\mathrm{pH} 3$, acetonitrile and methanol (40:50:10 - v:v). The flow rate was $1 \mathrm{~mL} / \mathrm{min}$. The wavelengths of the detection were at $220 \mathrm{~nm}$ for indomethazin and $230 \mathrm{~nm}$ for xylometazoline. The column oven temperature was $25{ }^{\circ} \mathrm{C}$ and the injection volume was $20 \mu \mathrm{L}$. The elution times for indomethazin and xylometazoline were 
approximately 10.5 and $4.2 \mathrm{~min}$, respectively (Pai et al. (2017))

\section{In vitro permeation studies}

The permeation studies were carried out by vertical diffusion cell method $\left(0.34 \mathrm{~cm}^{2}\right)$ thermostatted at $37^{\circ} \mathrm{C}$ in water bath (Variomag, Germany). The apparatus consisted of mixed cellulose ester membrane (Millipore) on to glass diffusion cell between donor and receptor compartments. The receptor solution was $5 \mathrm{~mL}$ of isotonic phosphate buffer: ethanol (3:2). The receptor solutions were magnetically stirred at 600 rpm throughout experiment. The donor compartment $\mathrm{w}$ as $0.5 \mathrm{~mL}$ of $\mathrm{F} 1$ emulsion or F2 emulsion or IND solution or XYL solution. The aliquots withdrawn at various intervals for 24 hours were immediately analysed for drug concentration with HPLC and refilled with the same volume of fresh receptor solution. Three replicates of each experiment were performed. Sink conditions were maintained in the receptor compartment during in vitro permeation studies.

\section{Data treatment}

The permeation of IND and XYL from nasal preparations was investigated. The cumulative amount-time profiles were plotted. The effective permeability coefficients and flux values at steady state were calculated (Karasulu et al. (2008)).

\section{Resarch Findings}

The characteristics of F1 and F2 emulsions such as particle size, $\mathrm{pH}$, conductivity, viscosity, measurements and final drug loading were given in Table 2.

Table 2. The composition (\%), particle size distribution, viscosity and final drug loading of water in two different oil emulsion $(\mathrm{O} / \mathrm{W})$. Each value indicates the mean $\pm \operatorname{SD}(n=3)$.

\begin{tabular}{lcc}
\hline & F1 & F2 \\
\hline Particle size $(\mathrm{nm}) \pm \mathrm{SD}$ & $136.8 \pm 24$ & $269.5 \pm 66$ \\
$\mathrm{pH}$ & 9.4 & 5.6
\end{tabular}

\begin{tabular}{lcc} 
Conductivity $\left(\mu \mathrm{Scm}^{-1}\right)$ & 4.9 & 2.2 \\
\hline $\begin{array}{l}\text { Drug loading }(\mathrm{mg} / \mathrm{mL}) \text { for } \\
\mathrm{IND} \pm \mathrm{SD}\end{array}$ & $1.0 \pm 0.04$ & $1.1 \pm 0.11$ \\
$\begin{array}{l}\text { Drug loading }(\mathrm{mg} / \mathrm{mL}) \\
\text { for XYL } \pm \mathrm{SD}\end{array}$ & $2.8 \pm 0.11$ & $1.7 \pm 0.14$ \\
Viscosity $(\mathrm{cp}) \pm \mathrm{SD}$ & $204.6 \pm 5$ & $192.2 \pm 14$ \\
\hline
\end{tabular}

Table 3. Flux and Peff IND\&XYL Through cellulose ester membrane from $\mathrm{F} 1$ and $\mathrm{F} 2$ formulations

\begin{tabular}{|l|l|l|}
\hline & Peff $(\mathrm{cm} / \mathrm{s})$ & $\mathrm{J}\left(\mathrm{cm}^{2} / \mathrm{s}\right)$ \\
\hline F1-XYL & $1.5 \mathrm{E}-03 \pm 3.52 \mathrm{E}-$ & $2,4 \mathrm{E}-03 \pm 5,86 \mathrm{E}-$ \\
04 & 04 \\
\hline F1-IND & $3.3 \mathrm{E}-03 \pm 9,20 \mathrm{E}-$ & $5,3 \mathrm{E}-03 \pm 1,53 \mathrm{E}-$ \\
& 04 & 03 \\
\hline F2-XYL & $\begin{array}{l}2.4 \mathrm{E}-03 \pm 6,41 \mathrm{E}- \\
04\end{array}$ & $\begin{array}{l}2,2 \mathrm{E}-03 \pm 4,89 \mathrm{E}- \\
04\end{array}$ \\
\hline F2-IND & $2.9 \mathrm{E}-03 \pm 8,42 \mathrm{E}-$ & $2,7 \mathrm{E}-03 \pm 6,67 \mathrm{E}-$ \\
& 04 & 04 \\
\hline
\end{tabular}

Fig. 1. In vitro permeation profiles of IND\&XYL into isotonic phosphate buffer-ethanol (3:2) (pH 7.4) at $37^{\circ} \mathrm{C}$ from nasal formulations using cellulose ester membrane. Each points represents the means of three assignations \pm SD.

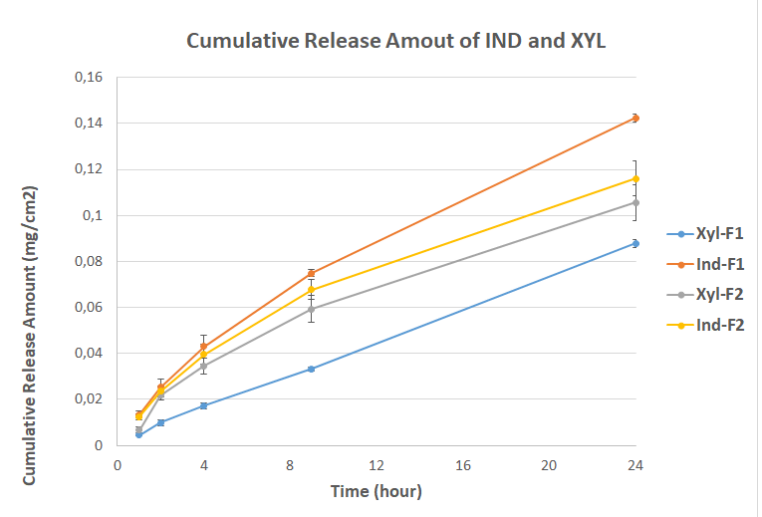

\section{Results}

\section{Particle size}

The particle size of $F 1$ and $F 2$ formulations were found to be $136.8 \pm 24 \mathrm{~nm}$ and $269.5 \pm 66$ $\mathrm{nm}$ respectively. The size range of macroemulsions is usually $0.1-5 \mu \mathrm{m}$. Polydispersity index determines the homogenity of the emulsion. For a 
homogeneous emulsion it should be $<1$ (Danaei et al. (2018)). It was found to be 0.3 for $\mathrm{F} 1$ and 0.5 for $\mathrm{F} 2$ respectively.

\section{pH}

The $\mathrm{pH}$ value of $\mathrm{F} 1$ and $\mathrm{F} 2$ emulsions were determined 9.4 and as 5.6 respectively. The nasal mucosal $\mathrm{pH}$ is $\approx 5.5-6.5$ which aproximating the normal $\mathrm{pH}$ range of nasal fluids (Ayoub et al (2016)). Nasal irritation could be minimized when Formulation 2 is used. It is in tolerable range in contact with nasal mucosa.

\section{Conductivity}

The $\mathrm{O} / \mathrm{W}$ emulsions provided higher conductivity values than the $\mathrm{W} / \mathrm{O}$ emulsions due to the conductivity properties of the aqueous external phase (Salager (2000)). The characteristics of $\mathrm{O} / \mathrm{W}$ emulsions such as conductivity measurements and final drug loading were given in Table 2.

\section{Drug content}

IND\& contents of the formulations F1-F2 were found 1.0-1.1 respectively. XYL contents for the F1-F2 formulations were found to be 2.8-1.7 respectively. The drugs contents of the formulations as shown in Table 2.

\section{In vitro permeation studies}

The profiles of permeation of IND \& XYL from $\mathrm{F} 1$ and $\mathrm{F} 2$ emulsion formulations through the cellulose ester membrane were shown in Fig. 1 In the study of Karasulu et al. (2008) it was shown that, different syntetic membrane filter separating the drug from the release medium did not impede drug release appreciably. According to the experimental results, in vitro flux values of IND\&XYL from these emulsions during 24 hours was found. The flux value of IND\&XYL during continuous permeability studies has been showed by a gradual increase in the receptor compartment as a function of time. The formulations of flux and peff IND\&XYL values as shown in Table 3. The release profiles of IND from F1 and F2 formulations are similar.

\section{Viscosity}

The viscosity of $\mathrm{F} 1$ and $\mathrm{F} 2$ formulations were found to be 204.6 \pm 5 and 192.2 \pm 14 respectively. Emulsions are more viscous systems that release solutions, and they extend the duration of the drug in the nasal cavity. Therefore, emulsions to solution are preferred for nasal administration, as the residence time of the drug at the site of action is extended (Kan et al. (1999), Tirucherai et al. (2002)).

Particle size distribution, viscosity and $\mathrm{pH}$ are the most important characterizations of formulation for evaluation of stability. A problem with the stability of the developed formulations has not been identified.

In conclusion, it is clear that emulsion formulation loaded with IND and XYL is potentially useful for in nasal delivery. Formulation of o/w emulsion IND and XYL may be considered as an alternative to iv and po administration. This administration may be IND and XYL delivery to achieve rapid onset of its pharmacological effect.

\section{References}

Ayoub, A.M., Ibrahim, M.M., Abdallah, M.H. Mahdy, M.A. (2016). "Sulpiride microemulsions as antipsychotic nasal drug delivery systems: In-vitro and pharmacodynamic study" Journal of Drug 
Delivery Science and Technology (36), 1022

Danaei, M., Dehghankhold, M., Ataei, S., Hasanzadeh, D.F., Javanmard, R., Dokhani, A., Khorasani S., Mozafari M.R. (2018). "Impact of particle size and polydispersity index on the clinical applications of lipidic nanocarrier systems" Pharmaceutics 2-17

Graf, C. Andreas Bernkop-Schnürch, A., $\quad$ Egyed, A., Koller, C. PrieschlGrassauer, E., Morokutti-Kurz, M. (2018). "Development of a nasal spray containing xylometazoline hydrochloride and iotacarrageenan for the symptomatic relief of nasal congestion caused by rhinitis and sinusitis" International Journal of General Medicine, (11) 275-283.

Huang, Z. L., Kagoshima, M., Kagawa, E. Shimada. H. (1995). "Absorption of indomethacin from nasal cavity in rats". Acta. Pharmacol. Sin (16)117-120

Kan, P., Chen, Z. B., Kung, R. Y., Lee, C. J., Chu, I. M. (1999). Study on the formulation of $\mathrm{o} / \mathrm{w}$ emulsion as carriers for lipophilic drugs. Colloids Surf B: Biointerfaces (15)117-125

Karasulu, H. Y., Şanal, Z. E., Sözer, S., Güneri, T., Ertan G. (2008). "Permeation studies of indomethacin from different emulsions for nasal delivery and their possible anti-inflammatory effects" AAPS PharmSci Tech, ( 9) 2, 342-348

Matsuyama T., Morita T., Horikiri Y., Yamahara H., Yoshino H. Improved nasal absorption of salmon calcitonin by powdery formulation with $\mathrm{N}$-acetyl-L-cysteine as a mucolyticagent. J. Control. Release 2006; 115:183-188.

Mitra R., Pezron I., Chu W. A., Mitra A. K. Lipid emulsions as vehicles for enhanced nasal delivery of insulin. Int. J. Pharm. 2000;205:127-134.

Pai, S., Sawant, N. (2017). "applications of new validated Rp-Hplc method for determination of indomethacin and its hydrolytic degradants using sodium acetate buffer drug" Indian Journal of Pharmaceutical Education and Research, 51(3), 388-392

Salager, J.L. (2000) "Pharmaceutical Emulsions and Suspensions" emulsion properties and related know-how to attain them Marcel Dekker, Inc. New York - Basel 74-122

Shekade S.V., Shirolkar, S.V., Chaudhari, Y. (2020). "Review on microemulsion drug delivery system for nasal application" $J$. Pharm. Sci. \& Res. 12(1), 63-73

Tirucherai, G.S., Pezron, I., Mitra, A. K. (2002). Novel approaches to nasal delivery of peptides and proteins. STP Pharma Sci (12)3- 12 